Social Work Pryshlyak, О. (2018). Особливості діяльності фахівців соціономічних професій в умовах \& Education полікультурності, Social Work and Education, Vol. 5, \& Education No. 4., pp. 66-75. DOI: 10.25128/2520-6230.18.4.6

๑) SW\&E, 2018

\title{
ОСОБЛИВОСТІ ДІЯЛЬНОСТІ ФАХІВЦІВ СОЦІОНОМІЧНИХ ПРОФЕСІЙ В УМОВАХ ПОЛІКУЛЬТУРНОСТІ
}

\author{
Oksana Pryshlyak, \\ Candidate of Pedagogical Sciences, \\ Associate Professor \\ Department of Foreign Languages \\ Ternopil Volodymyr Hnatyuk \\ National Pedagogical University \\ Ternopil, Ukraine \\ pryshlyak_o@yahoo.com
}

\section{Оксана Пришляк,}

кандидат педагогічних наук, доиент кафедри іноземних мов, Тернопільський начіональний педагогічний університет імені Володимира Гнатюка, м.Тернопіль, Україна

УДК 371.134.

DOI: $10.25128 / 2520-6230.18 .4 .6$

\section{Article history:}

Received: October 10, 2018

1st Revision: November 17, 2018

Accepted: December 30, 2018
АНОТАЦІЯ. У статті розкрито особливості діяльності фахівців соціономічних професій в умовах зростання диверсифікованості та полікультурності суспільства; висвітлено сутність професійної діяльності фахівців соціономічної сфери; підходи різних науковців до розуміння сутності та завдань соціономічних професій; подане узагальнене визначення соціономічних професій: соціономічними (комунікативними, соціальними) у сучасній науці прийнято називати професії типу «людиналюдина», тобто професії, у змісті фахової діяльності яких переважають ситуації міжособистісної ділової комунікації. Окреслено рівні діяльності фахівців соціономічних професій. Схарактеризовано міжкультурну компетентність як процес оволодіння культурою, спрямований на змінурозвиток, цілісне формування особистості фахівця, становлення його як суб'єкта культури; соціальний i полікультурний досвід, який $€$ основою вирішення життєво важливих завдань; самовизначення, самоідентифікацію i набуття міжкультурної компетентності та культурної ідентичності як результат освітнього процесу, та іï компоненти: культурнопсихологічну, соціокультурну, діяльнісну, рефлексивнотворчу (особистісну). Обгрунтовано, чому саме фахівці соціономічних професій відіграють ключову роль у реалізації завдань полікультурної освіти та забезпеченні міжкультурного взаєморозуміння у суспільстві. Розкрито особливості діяльності фахівців соціономічних професій: людиноорієнтованість, висока комунікативна активність, толерантність, соціабельність, емпатійність, спрямованість на вирішення проблем, альтруїз, готовність до моделювання ситуацій міжособистісної взаємодії, відсутність стереотипів та упереджень, розвиваючий та творчий характер діяльності тощо.

Ключові слова: професії соціономічної сфери; фахівці соціономічних професій; особливості діяльності фахівців соціономічних професій; полі культурність; міжкультурна компетентність. 


\section{Вступ}

Сучасна парадигма освіти велику увагу приділяє проблемам виховання i навчання у багатонаціональному соціумі. В умовах глобалізації більшості суспільних процесів особлива місія відводиться полікультурній освіті, яка нерозривно пов'язана 3 питаннями діалогу культур та міжкультурної комунікації. Очевидно, що в сучасному соціумі, який $€$ зазвичай полікультурним, мультиетнічним, різнорелігійним, полікультурна компетентність фахівця стає невід'ємною компонентою професійної компонентності. Ключову роль у реалізації завдань полікультурної освіти та забезпеченні міжкультурного взаєморозуміння у суспільстві відіграють фахівці соціономічних професій, метою професійної діяльності яких $\epsilon$ підтримка, розвиток соціального життя людини, гармонізація стосунків у суспільстві, аналіз та прогнозування розвитку та наслідків соціальних процесів (Буркова, 2010; Berezan, 2018). Диверсифікованість сучасного суспільства вимагає нових підходів до підготовки фахівців професій типу «людина-людина», оскільки полікультурне середовище часто є чинником виникнення комунікативних бар'єрів та труднощів соціальної адаптації особистості. Вирішення проблеми професіоналізму й умов його забезпечення в закладах вищої освіти на основі полікультурної освіти стає важливим завданням формування особистісних якостей i поведінки майбутніх фахівців соціономічної сфери. За таких умов необхідне поглиблене вивчення соціономічних професій, виокремлення та врахування їхніх особливостей для максимальної адаптації представників людиноорієнтованих професій до роботи в умовах полікультурності як невід’ємної характеристики більшості сучасних соціумів.

\section{Аналіз останніх публікацій.}

Дослідження особливостей та типологічної специфіки соціономічних професій здійснюють В. Болучевська, Т. Браніцька, Л. Буркова, Г. Дубчак, Р. Каверіна, В. Корнещук, В. Мілакова, Н. Провоторова, Н. Рабецька, І. Тормажевська, О. Тюптя, О. Чичук. Різні підходи до класифікації професій соціономічного плану у своїх наукових дослідженнях аналізують А. Бойко, А. Букалов, В. Гуленко, М. Лукашевич, В. Тищенко.

Методолого-теоретичні основи полікультурності як соціокультурного феномена розкриті у наукових працях Н. Авшенюк, Дж. Гартлі, С. Драгоєвича, Д. Кемпбелл, В. Макаєва, В. Погребняка, Л. Супрунової, А. Сбруєвої, Н. Якси. Полікультурну компетентність як психолого-педагогічну складову сучасного освітнього процесу вивчають О. Гуренко, Р. Кравець. Формування особистіснопрофесійних якостей фахівців соціономічних професій у контексті формування міжкультурної компетентності $\epsilon$ предметом наукового пошуку А. Скрипкіної, О. Гіріна. Попри це аналіз наукової психолого-педагогічної та соціологічної літератури засвідчує відсутність цілісних досліджень у предметному полі функціонування соціономічних професій в умовах полікультурності, що актуалізує дану проблему й вимагає активізації наукових розвідок у цьому напрямі.

Мета статті: розкриття особливостей діяльності фахівців соціономічних професій в умовах зростання диверсифікованості та полікультурності суспільства. 


\section{Основна частина}

Соціально-політичні та культурно-демографічні трансформації, що відбуваються у світі, де більшість держав є багатоетнічними за своїм складом, спонукають до пошуку адекватних рішень проблем, пов'язаних 3 урахуванням інтересів представників усіх етнокультурних груп суспільства. Одним із важливих кроків на цьому шляху є підготовка фахівців соціономічних професій до роботи в умовах полікультурного середовища.

Соціономічними (комунікативними, соціальними) у сучасній науці прийнято називати професії типу «людина-людина», тобто професії, у змісті фахової діяльності яких переважають ситуації міжособистісної ділової комунікації. Ці професії пов'язані з такими сферами як: медичне обслуговування (лікар, медсестра), навчання i виховання (вихователь, гувернер, тренер, вчитель), побутове обслуговування (продавець, провідник, офіціант), правовий захист (юрист, поліцейський). Окремо в цій групі можна виділити сфери діяльності, пов'язані з наданням тієї чи іншої допомоги чи послуг людині, групам людей (лікар, психолог, педагог, соціальний працівник та інші) (Браніцька, 2012).

Таким чином, в основу соціономічної діяльності покладена так звана допомагаюча поведінка (допомагаючі взаємостосунки) - термін, запропонований К. Роджерсом (C. Rogers) для позначення взаємин, у яких простежується сприяння розвитку, благополуччю, вдосконаленню партнера, i яке в ідеалі має бути двостороннім (Роджерс, 2001, с. 193).

На думку Ш. Тейлора (S. Taylor), Л. Піпло (L. Peplau), Д. Cipca (D. Sears) допомагаючу поведінку можна трактувати як просоціальну - сукупність певних дій, що спрямовані на допомогу людям у вирішенні їхніх проблем [14, с. 89]. Таким чином, професійна діяльність лікарів, педагогів, соціальних працівників, психологів та інших фахівців соціономічної сфери є фактично реалізацією допомагаючої або просоціальної поведінки.

Л.M. Брамер (L.M. Brammer) і Дж. МакДоналд (G. MacDonald) виокремлюють структуровану та неструктуровану допомагаючу діяльність. До структурованої дослідники відносять професійну та волонтерську діяльність, до неструктурованої дружні, родинні, будь-які інші неформальні соціальні стосунки. Особливістю соціономічних професій є те, що допомагаюча діяльність стає головним елементом професійної активності. Іншими словами, неструктурована допомога набуває структурованого характеру, коли суб'єкт допомоги починає усвідомлено та цілеспрямовано застосовувати спеціальні знання та навички (Brammer Lawrence \& Macdonald, 1998).

Базовою характеристикою соціономічних професій є соціальні стосунки, що здійснюються в системах «фахівець-клієнт», «фахівець-група/групи клієнтів». Соціальні стосунки регулюються між фахівцем та клієнтами соціальними нормами, що існують в суспільстві. Основним завданням соціономічних професій є підтримка, розвиток соціального життя людини, гармонізація стосунків у суспільстві, аналіз та прогнозування розвитку і наслідків соціальних процесів (Буркова, 2010). Професійна взаємодія представників соціономічних професій із клієнтами надає цим відносинам соціальну сутність і дозволяє реалізувати соціальні сподівання обох учасників соціальної взаємодії. Для цього фахівець у системі професій типу «людина-людина» 
має володіти творчим складом розуму, здатністю моделювати варіанти міжособистісної та міжкультурної взаємодії. При цьому критеріями успішної діяльності фахівців даної сфери стають адаптованість, ідентифікація Я-образу 3 обраним фахом, відданість професії.

Специфіка соціономічних професій полягає в тому, що людина або людська спільнота тут не виступають як соціальне середовище, умова діяльності, а розглядаються в якості об'єкта і предмета діяльності.

Г. Дубчак стверджує, що діяльність фахівця у соціономічних професіях можна охарактеризувати як таку, що протікає в умовах постійно мінливого середовища; надзвичайно багатопланову, багатоаспектну, насичену великою кількістю різноманітних дій; наповнену взаємодією з іншими людьми; яка часто реалізується в умовах вираженого дефіциту часу; опосередковану стосовно результатів діяльності роботою інших людей (Дубчак, 2015, с. 43-50).

На думку С. Вакуленко, соціальна взаємодія між фахівцем, який представляє соціономічну професію, з одного боку, і клієнтом, з іншого боку, здійснюється через форму зв'язків, які реалізуються в процесі обміну вміннями, досвідом, навичками, знаннями, вербальними та конкретними діями» (Вакуленко, 2008, с. 15).

Л. Буркова функціональне призначення соціономічних професій вбачає у їхньому впливі на соціальну взаємодію через соціальну організацію, соціальне управління, соціальне дослідження, створення механізмів соціального розвитку, корекцію (регуляцію), соціальну підтримку, трансформацію (у різні сфери діяльності, зміст освіти), формування соціальних стосунків на всіх суспільних рівнях та створення соціальних систем (Буркова, 2010).

До функцій, які реалізуються в процесі діяльності фахівцями соціономічних професій, зазвичай відносять: уточнення соціальних і міжособистісних проблем окремих осіб; освіту і виховання підростаючого покоління; соціальну підтримку окремих осіб і соціальних груп; експертизу соціальних і міжособистісних проблем; функцію соціального захисту окремих осіб; сприяння формуванню в суспільстві толерантного ставлення до осіб з різних етнокультурних груп; сприяння збереженню національних етнокультурних цінностей тощо.

Аналізуючи сутність праці фахівців соціономічних професій Р. Каверіна акцентує увагу на таких атрибутах їх професійної діяльності: характеристики індивіда або соціальної групи (соціальний стан, професія, місце роботи, вік, стать); елементи експресії (особливості сприйняття фахівця соціономічної професії, його мовлення, міміки тощо); індивідуальні особливості (особистісні потреби, інтереси, зовнішній вигляд, одяг тощо); психофізичний стан (стан здоров'я, емоційна стійкість (нестійкість), збудженість, байдужість, врівноваженість тощо) (Каверина, 1978, с.65).

Відповідно, реалізація функцій соціономічної діяльності неможлива без наявності у фахівця певних особистісних якостей, таких як: альтруїзм, людяність, чуйність; толерантність, гнучкість у спілкуванні; емпатійність, спроможність до налагодження довірливих стосунків із клієнтом; ентузіазм і оптимізм; упевненість в собі, позитивне самосприйняття, адекватна самооцінка; психологічні якості (відповідальність, комунікабельність самоконтроль, самокритичність); психологічні характеристики (стресостійкість, здатність до тривалих психологічних навантажень). Йому повинні бути притаманні високий рівень життєвих домагань, спрямованість на 
досягнення професійного успіху. Він мусить бути спроможним до конструктивного, адекватного та морального самовираження, самореалізації, зоріснтованим на постійний пошук нових методів роботи.

Соціономічні професії передбачають, що сутність фахової діяльності їх представників - це активна робота 3 людьми 3 метою вирішення чи надання допомоги у вирішенні їхніх проблем. У сучасних умовах це вимагає від представників соціономічних професій не лише фахових знань, умінь і навичок, психологічної стійкості, професійної компетентності, але й володіння технологіями професійного спілкування, культури поведінки тощо.

Як цілком слушно зауважуе В. Корнещук, специфіка професійної діяльності в соціономічній сфері насамперед полягає в тому, що вона здійснюється в умовах постійного й безперервного спілкування, тобто основним засобом реалізації професійної діяльності є комунікація, яка складається фактично з трьох процесів: інтерактивного (налагоджує i регулює взаємодію суб'єктів спілкування), інформативного (здійснює обмін інформацією між суб'єктами і іï аналіз) i перцептивного (здійснює рефлексію, взаємооцінку і взаємосприйняття суб'єктами один одного) (Андреева, 1997, с. 193; Корнещук, 2010, с. 12). Роль комунікації особливо зростає в умовах полікультурного середовища, коли існуючі труднощі взаємодії між фахівцем та клієнтом можуть ускладнюватися культурними відмінностями.

Л. Буркова стверджує, що предметом праці, що єднає представників різних соціономічних професій, $€$ міжособистісні відносини соціального характеру на різних рівнях взаємодії:

1) рівні загальносуспільної взаємодії між соціальними, етнокультурними $\mathrm{i}$ релігійними групами - мікрорівень;

2) рівні соціальної міжсуб'єктної (міжоб'єктної) взаємодії із людьми, соціальними, етнокультурними групами - мезорівень;

3) рівні трудових, професійних відносин у трудовому колективі (організація роботи колективу, обрання стратегії і тактики реалізації професійних проектів, вирішення завдань, обмін досвідом роботи тощо) - макрорівень (Буркова, 2010, с. $38)$.

Зважаючи на те, що професійна підготовка фахівців соціономічних професій $\epsilon$ багаторівневою динамічною системою, яка активно модернізується, враховуючи різноманітні суспільні чинники, в тому числі й усе зростаючу полікультурність суспільства, вона вимагає грунтовного підходу до формування професійної компетентності та її складових: педагогічної, психологічної, міжкультурної та інших.

На кожному 3 рівнів діяльності фахівців соціономічних професій мультикультурність як соціальна характеристика висуває специфічні вимоги до професійної компетентності фахівця, оскільки міжкультурна компетентність виступає важливою умовою не тільки професійної діяльності але й успішної соціальної взаємодії особистості в сучасному багатонаціональному суспільстві, інтеграції у світове етнокультурне різноманіття. Це дозволяє розглядати формування міжкультурної компетентності як процес оволодіння культурою, спрямований на зміну-розвиток, цілісне формування особистості фахівця, становлення його як суб'єкта культури; соціальний і полікультурний досвід, який є основою вирішення 
життєво важливих завдань; самовизначення, самоідентифікацію i набуття міжкультурної компетентності та культурної ідентичності як результат освітнього процесу (Гуренко, 2015).

Міжкультурна компетентність $є$ інтегративною особистісною характеристикою, що включає:

1. Культурно-психологічну компоненту, що визначається сукупністю когнітивної та мотиваційної (ціннісно-смислової) складових. У структуру мотиваційної складової входять: потреби у полікультурному розвитку, власній системі ціннісних орієнтацій; здатність до рефлексії; визначення своєї ролі, статусу і функцій у сучасній культурі, актуалізація полікультурного контексту соціального середовища та освіти в умовах полікультурності.

У структуру когнітивної складової входять: розуміння і прийняття культурного розмаїття світу, оволодіння полікультурними знаннями (фактами, уявленнями, поняттями, законами), символами, традиціями, нормами, притаманними різним культурним, етнічним, соціальним, релігійним спільнотам.

2. Соціокультурна компонента, що включає знання історичних фактів, сутності сучасної соціокультурної системи; вміння орієнтуватися у традиціях, звичаях i духовних цінностях як своєї, так й інших соціокультурних спільнот; вміння встановлювати контакт зі співрозмовником у ситуаціях полікультурного характеру; доброзичливе, відкрите і неупереджене ставлення до будь-якої культури й ії носіїв; розуміння закономірностей розвитку культури як безперервного процесу зі створення, збереження і трансляції загальнолюдських цінностей; готовність до соціалізації в умовах зростаючої інтеграції світової спільноти.

3. Діяльнісна компонента передбачає здатність проникати в сутність іншої культури, робити необхідні узагальнення на матеріалі конкретних одиничних прикладів; вміння розпізнавати культурну конотацію іншомовної лексики; вміння ставитися до носіїв чужої культури і самої культури з емпатією, толерантністю, не формувати судження лише на основі прийнятих у власній культурі норм і правил; вміння та навички продуктивної взаємодії з носіями інших культурних спільнот.

4. Рефлексивно-творча (особистісна) компонента характеризується: самостійністю, гнучкістю та варіативністю мислення і творчої діяльності; високим рівнем комунікативних умінь; здатністю i готовністю до саморозвитку i самореалізації; входженням у рефлексивну позицію i творче перетворення в ситуаціях полікультурного наповнення; умінням прогнозувати наслідки своїх дій; осмисленням ціннісної основи своєї діяльності (Деречин, 2013).

В умовах мультикультурного середовища допомагаюча діяльність фахівців соціономічних професій спрямована на сприяння клієнту в процесі адаптації до умов соціального середовища, різноманітного у культурних, гендерних, релігійних, етнічних проявах. Такий підхід надає діяльності фахівців соціономічних професій яскраво вираженого морально-етичного характеру. При цьому фахівець має володіти високим рівнем насамперед компетенцій міжособистісної взаємодії, до яких відносимо:

- навички активного та рефлексивного слухання;

- вміння дистанціюватись від власних культурних стереотипів;

- володіння повним інструментарієм для налагодження взаємодії 
представниками інших культур та соціальних спільнот;

- вміння оцінити ставлення клієнта до проблемної ситуації, самого фахівця, готовність реорганізувати ситуацію з метою покращення взаємодії;

- здатність виступати посередником між домінантною культурою i культурою меншості, носієм якої є клієнт;

- вміння визначити та мобілізувати ресурси кліснта;

- вміння вчасно зробити паузу в роботі для аналізу ситуації;

- вміння ідентифікувати клієнта як надійне джерело інформації, що має своє бачення власної проблемної ситуації (Compte-rendu des travaux de l'Atelier ..., 2012).

Основні цілі підготовки фахівців соціономічних професій до роботи в умовах полікультурного середовища мають відповідати загальним завданням полікультурної освіти:

1) засвосння знань про власну культурну спадщину в загальносвітовому цивілізаційному контексті, формування уявлень про культурну різноманітність $\mathrm{i}$ паритетність (культурна ідентифікація);

2) забезпечення позитивного ставлення до культурних відмінностей через виховання полікультурної свідомості (полікультурна мотивація);

3) розвиток практичних умінь взаємодії у полікультурному просторі на засадах порозуміння та демократії (полікультурна компетентність) (Погребняк, 2013, с. 362363).

Модель професійної підготовки фахівців професій соціономічного типу до роботи в умовах полікультурності також має відображати вимоги, що пред'являються суспільством і державними стандартами до професійної підготовки майбутніх фахівців соціономічної сфери; основні результати наукових розвідок з проблеми дослідження; організаційні засади процесу підготовки майбутніх фахівців; зміст як професійної підготовки, так і самоосвіти.

\section{Висновки}

Узагальнюючи вищесказане можемо стверджувати, що особливостями сучасних соціономічних професій $\epsilon$ їхня людиноорієнтованість, висока комунікативна активність фахівців, толерантність, соціабельність, емпатійність, спрямованість на вирішення проблем, альтруїзм, готовність до моделювання ситуацій міжособистісної взаємодії, відсутність стереотипів та упереджень, розвиваючий та творчий характер діяльності тощо. В умовах полікультурності соціономічні професії все більше набувають фасилітаційної та адаптаційної функцій. У такому контексті підготовка фахівців професій соціономічного типу до роботи у полікультурному середовищі із врахуванням зазначених особливостей передбачає також оволодіння системою полікультурних знань, сформованих ціннісних орієнтацій, пріоритетів полікультурного середовища i засобів його аналізу; формування механізмів, прийомів і способів рефлексії та саморегуляції на рівні вирішення нестандартних ситуацій, прогнозування розвитку ситуацій і подій у полікультурному середовищі; готовність до здійснення комунікації в полікультурному середовищі, проектування варіантів поведінки представників полікультурного середовища. 


\section{Література}

Андреева, Г.М. (1997).Социальная психология. М.: Аспект-Пресс, 375.

Браніцька, Т.Р. (2012). Загальна характеристика фахівця соціономічної професії. Збірник наукових праць Хмельниџького інституту соиіальних технологій Університету «Україна». [Електронний ресурс] Режим доступу: http://nbuv.gov.ua/UJRN/ Znpkhist 20126 7. Мова укр. (6). 25-28..

Буркова, Л.В.(2010). Визначення класу соціономічних професій. Практична психологія та соиіальна робота. (7), 68-73.

Вакуленко, С. М. (2008). Соціологія праці: навч.-метод. посібник. К.: Знання, 262.

Гуренко, O.I. (2015). Теоретичні і методичні засади полікультурної освіти майбутніх соціальних педагогів: дис. д-ра пед. наук: 13.00.04 - теорія і методика професійної освіти, Національний педагогічний університет ім. М.П. Драгоманова. К., 580.

Деречин, A.O. (2013). Структурно-содержательная $\quad$ характеристика поликультурной компетентности старшеклассников. Вестник Шадринского государственного педагогического университета. (1 (17)), 31-36.

Дубчак, Г. М. (2015). Порівняльний аналіз стресостійкості майбутніх фахівців соціономічних професій. Актуальні проблеми психології : Збірник наукових праць / За ред. С. Д. Максименка. К.: Інформ.-аналіт. агентство, Т. 5: Психофізіологія. Психологія праці. Експериментальна психологія. Вип. 15, 43-50.

Каверина, Р. Д. (1978). Опит психологической классификации некоторых профессий в целях профконсультации. Вопросы психологии. (4), 64-73.

Корнещук, В. В. (2010). Теорія і практика формування професійної надійності майбутніх спеціалістів соцономічної сфери діяльності: автореф. дис. ... д-ра пед. наук: 13.00.04 / Вікторія Вікторівна Корнещук . Одеса, 44.

Погребняк, В. (2013). Міжнародна концепція полікультурного виховання. Педагогіка вищої та середної школи. Вип. 37, 359-363.

Роджерс, К.Р. (2001). Становление личности: Взгляд на психотерапию. М.:Эксмо-Пресс, 416.

Berezan, V. (2018). The emergence and development of socionomic professions in the international educational space. Social work and education, 5(1), 47-56.

Brammer Lawrence, M., Macdonald, G. (1998). Helping Relationship: The Process and Skills. Allyn and Bacon, 198.

Compte-rendu des travaux de l'Atelier Cooperatif de Recherche-Action «Travail social et developpement de connaissances et competences interculturelles». (2012). 24.

Campbell, S. M., Peplau, L. A., \& Sears, D. O. (2003). Test Item File [for] Social Psychology, [by] Shelley E. Taylor, Anne L. Peplau, David O. Sears. Prentice Hall. 


\section{THE PECULIARITIES OF ACTIVITIES OF SOCIONOMIC PROFESSIONS' REPRESENTATIVES IN INTERCULARITY CONDITIONS}

Pryshlyak Oksana, Candidate of Pedagogical Sciences, Associate Professor, Department of Foreign Languages, Ternopil Volodymyr Hnatyuk National Pedagogical University, Ternopil, Ukraine

Abstract. The article reveals the peculiarities of the activities of representatives of socionomic professions in the conditions of increasing diversification and multiculturalism of society. The essence of professional activity of representatives of socionomic professions is revealed, the purpose of which is support, development of social life of a person, harmonization of relations in society, analysis and forecasting of development and consequences of social processes. The approaches given by different scholars to the understanding of the essence and tasks of socionomic professions (T. Branick, L. Burkova, S. Vakulenko, G. Dubchak, R. Kaverina and others) are revealed. The generalized definition of socionomic professions is proposed: sociological (communicative, social) in modern science is called the type "human-human professions", that is, professions whose main occupation is dominated by situations of interpersonal business communication. Levels of activity of representatives of socionomic professions are outlined: level of general social interaction between social, ethnocultural and religious groups (micro level); the level of social interpersonal (interobject) interaction with people, social, ethno-cultural groups (meso-level); the level of labor, professional relations in the staff (organization of staff work, the choice of strategy and tactics for the implementation of professional projects, problem solving, exchange of work experience, etc.) (macro level). The author characterized intercultural competence as a process of mastering culture, aimed at changedevelopment, holistic formation of the personality of a specialist, the formation of a specialist as a subject of culture; social and multicultural experience that is the basis of solving vital tasks; self-identification, and acquisition of intercultural competence and cultural identity as a result of the educational process, and its components: cultural and psychological, social and cultural, reflexive and creative (personal). It is substantiated why social specialists play a key role in the realization of the tasks of multicultural education and ensuring intercultural understanding in society. The peculiarities of the activity of social specialists are revealed: human-oriented, high communicative activity, tolerance, empathy, orientation to solving problems, altruism, readiness to model situations of interpersonal interaction, lack of stereotypes and prejudices, developmental and creative nature of activity, etc.

Key words: professions of socionomic sphere; representatives of socionomic professions; peculiarities of activities of socionomic representatives; assisting activities; levels of activity of of representatives of socionomic professions; interculturality; intercultural competence. 


\section{Reference}

Andreeva, G.M. (1997). Social psychology. M .: Aspect-Press, 375 (in ukr).

Branitska, T.R. (2012). General characteristics of a representative of socionomic profession. Collection of scientific works of the Khmelnytsky Institute of Social Technologies of the University "Ukraine". [Electronic resource] Access mode: http://nbuv.gov.ua/UJRN/Znpkhist_2012_6_7. Language Ukr. (6). 25-28 (in ukr).

Burkova, L.V. (2010). Definition of the class of socionomic professions. Practical Psychology and Social Work. (7), 68-73 (in ukr).

Vakulenko, S.M. (2008). Sociology of labor: teaching method. manual. K.: Znannya, 262 (in ukr).

Gurenko, O.I. (2015). Theoretical and methodical principles of multicultural education of future social educators: Scientific thesis Dr. Ped. Sciences: 13.00.04 Theory and Methodology of Profesional Education, National Pedagogical Drahomanov University. K., 580 (in ukr).

Derechin, A.O. (2013). Structural-content characteristic of multicultural competence of senior pupils. Bulletin of the Shadrin State Pedagogical University. (1 (17)), 31-36 (in ukr).

Dubchak, G.M. (2015). Comparative analysis of the stress resistance of future specialists of socionomic professions. Actual problems of psychology: Collection of scientific works / Ed. Maksimenko S. K.: Inform-analit. agency, V. 5: Psychophysiology. Psychology of labor. Experimental psychology. (15), 43-50 (in ukr).

Kaverina, R.D. (1978). Experience in the psychological classification of certain professions for the purpose of professional consultation. Psychology issues. (4), 64-73 (in $\mathrm{ukr}$ ).

Korneshchuk, V.V (2010). Theory and practice of formation of professional reliability of future representatives of socionomic professions: author's abstract. dis ... Dr. Ped. Sciences: 13.00.04 / Victoria Viktorivna Korneschuk. Odessa, 44 (in ukr).

Pogrebnyak, V. (2013). International concept of multicultural education. Pedagogy of higher and secondary schools. (37), 359-363 (in ukr).

Rogers, K.R. (2001). Formation of personality: View of psychotherapy. M.: Exmo-Press, 416 (in ukr).

Berezan, V. (2018). The emergence and development of socionomic professions in the international educational space. Social work and education, 5 (1), 47-56 (in ukr).

Brammer Lawrence, M., McDonald, G. (1998). Helping Relationship: The Process and Skills. Allyn and Bacon, 198

Compte-rendu des travaux de l'Atelier Cooperatif de Recherche-Action "Travail social et developpement de connaissances et competences interculturelles". (2012). 24

Campbell, S. M., Peplau, L.A. \& amp; Sears, D.O. (2003). Test Item File [for] Social Psychology, [by] Shelley E. Taylor, Anne L. Peplau, David O. Sears. Prentice Hall. 